\title{
The Relationship between Firms' Characteristics in the Periods Prior to Bankruptcy Filing and Bankruptcy Outcome
}

\author{
Ena Rose-Green (Corresponding Author) \\ College of Business Administration, University of Alabama in Huntsville \\ Huntsville, AL 35899, USA \\ Tel: 1-256-824-6888Ｅ-mail: ena.rose-green@uah.edu \\ Linda Lovata \\ Department of Accounting, \\ School of Business, Southern Illinois University Edwardsville \\ 2103 Founders Hall, Edwardsville, IL 62026, USA \\ Tel: 1-618-650-2623Ｅ-mail: 1lovata@siue.edu
}

Received: January 17, 2013

doi:10.5430/afr.v2n1p97
Accepted: February 12, 2013

Online Published: February 20, 2013

\begin{abstract}
This study examines the association between firms' characteristics in the years prior to bankruptcy filing and bankruptcy outcome for firms filing Chapter 11 bankruptcy petitions. Our results indicate that, up to three years prior to bankruptcy filing, the characteristics of firms that liquidate differ from those of firms that reorganize. Three years prior to bankruptcy, the firms that subsequently reorganize are larger and have higher leverage than the firms that subsequently liquidate. (This relationship remains constant for all three years studied.) Two years prior to bankruptcy filing, firms that eventually reorganize are more solvent and have higher levels of discretionary accruals than firms that eventually liquidate. In the year prior to filing, firms that subsequently liquidate are more likely to have positive discretionary accruals. These findings suggest that stakeholders can predict the eventual outcome of Chapter 11 filings long before the court ruling.
\end{abstract}

Keywords: Earnings management, Discretionary accruals, Bankruptcy outcome

\section{Introduction}

Bankruptcy is an economic event that is likely to result in significant losses to the stakeholders of a firm [see Beneish and Press (1995), Chen and Church (1996) and Dawkins and Bamber (1998)]. Extant accounting research has shown that the magnitude of the loss is strongly correlated with the eventual resolution of bankruptcy. Stakeholders in firms that are liquidated are likely to suffer greater losses than stakeholders in firms that are reorganized(Rose-Green and Dawkins 2000). The ability to predict the final disposition of bankruptcies in a timely manner should therefore be helpful in mitigating investor losses. To provide empirical evidence that could be useful to stakeholders in making informed decisions, this paper examines the association between bankruptcy outcome and firm characteristics in the three years prior to bankruptcy filing. The characteristics examined are leverage, liquidity, solvency and levels of earnings management.

We investigate the association between firm characteristics and bankruptcy outcome by performing both univariate and regression analyses on a sample of 208 firms that filed Chapter 11 bankruptcy petitions between 1991 and 2004. To date, there are no longitudinal studies that identify changes in firm characteristics prior to bankruptcy filing. Using a study by Bryan, Tiras and Wheatley (2002) as a foundation, we examine the association between liquidity, solvency and bankruptcy outcome. Our study extends Bryan et al. (2002) by investigating a three-year test period (compared to the year prior to the bankruptcy filing), updating the sample, and including earnings management in the analysis. We also examine the association between firm leverage and bankruptcy outcome. Finally, prior studies have yielded conflicting results regarding bankruptcy outcome and liquidity, so this study will provide additional evidence to inform that debate. 
Our overall results indicate no significant association between liquidity, solvency, discretionary accruals and bankruptcy outcome three years prior to bankruptcy filing. However, the subsequently reorganized firms are more highly leveraged. Two years prior to bankruptcy filing, we find a significant association between bankruptcy outcome and firm size, liquidity and leverage. We find that firms that are larger, more liquid and have higher leverage are more likely to reorganize. Additionally, we find that subsequently reorganized firms have higher levels of discretionary accruals. In the year prior to bankruptcy filing, subsequently reorganized firms remain more liquid with higher leverage but also are more solvent than the subsequently liquidated firms. The subsequently liquidated firms are more likely to report positive discretionary accruals. This may indicate that companies that eventually reorganize start planning earlier. Earnings management may be positively related to reorganization as long as it is done well in advance of the filing.

This study contributes to the bankruptcy and earnings management literature by providing empirical evidence of the association between firm characteristics in the periods prior to bankruptcy filing and bankruptcy outcome. Our study provides empirical evidence that could be useful to firms' stakeholders in making informed decisions. We provide information that could help stakeholders predict the final disposition of bankruptcy in a timely manner. Additionally, the fact that liquidated firms tend to show positive discretionary accruals in the year prior to bankruptcy filing indicates that it is unlikely that managers can successfully manipulate bankruptcy outcome by managing earnings upward in the period prior to bankruptcy filing.

The remainder of this paper is organized as follows. The next section provides some background on the Chapter 11 process and discusses the motivation for the study. This is followed by a description of the sample and the model tested. The results are then presented along with some sensitivity tests. The final section provides a summary and some concluding remarks.

\section{Background and Motivation}

In the U.S., companies in severe financial distress have the option of filing for Chapter 7 or Chapter 11 bankruptcy protection. If the company plans to liquidate, Chapter 7 is the appropriate channel. Chapter 11 is initiated if the company expects to be reorganized. However, many firms filing under Chapter 11 do not come to terms with their creditors and are liquidated by the courts. This study investigates the characteristics of companies filing Chapter 11 that are liquidated versus reorganized during the three years prior to the Chapter 11 filing. In addition to examining the duration of differences found in prior studies, we examine earnings management, defined as discretionary accruals.

The recent increase in the number and size of firms filing for protection under Chapter 11 has resulted in significant interest in the economic issues surrounding bankruptcy. Also, potential bankruptcy provides strong motivation for earnings manipulation by managers. Reorganization as the outcome of the Chapter 11 filing, therefore, may be associated with "successful" earnings management. If stakeholders do not detect the earnings management, they may be more willing to accept a reorganization plan.

\subsection{The Chapter 11 Process.}

The Chapter 11 process protects the filing firm by prohibiting creditors from taking actions against the firm while a reorganization plan is being negotiated. This allows firms to postpone repayments of interest and capital until reorganization is complete. The goal is to allow the firm to continue operating while the reorganization plan is being settled. Management of companies that file Chapter 11 bankruptcy petitions retain control and actively participate in the reorganization plan. The initial reorganization plan is proposed by the established management within 120 days of filing (Jensen 1991). The bankruptcy court appoints committees to represent the interests of shareholders and each class of creditors. The committees work with management to develop a reorganization plan.

The reorganization plan must be ratified by the majority of stockholders and creditors and approved by the court. Within each class of creditors, there must be agreement by a two-thirds majority based on market value and a simple majority based on number. Once a plan is developed, it is filed with the court. The bankruptcy judge is given the choice of accepting the plan and allowing the firm to be reorganized or rejecting the plan and either calling for a new plan or calling for the liquidation of the firm. The judge can also confirm a plan that has been rejected by the shareholders and/or creditors, as long as the plan treats creditors and shareholders fairly. If the outcome of bankruptcy filing is liquidation, the court appoints a trustee to sell the company's assets and pay off the company's stakeholders. The secured creditors are first paid followed by the unsecured creditors. The shareholders, as the residual claimholders, are last in line. 


\subsection{Prior Literature}

Prior research has contrasted, in the year before bankruptcy, the characteristics of companies that reorganize and companies that liquidate. Bryan, et al. (2002) find that the resolution of bankruptcy is associated with the solvency and liquidity risks of the firm. Additionally, a working paper by Jacobs, Karagozoglu and Naples Layish (2008) reports that higher leveraged companies with less liquidity the year before bankruptcy filing are more likely to be reorganized. Our paper will extend these studies by looking at these characteristics in the three years prior to bankruptcy to see when the companies first display the differences noted by these prior studies. Additionally, we will examine the association between earnings management during this time period and bankruptcy outcome.

Managers communicate financial information to the stakeholders of a company primarily through financial reporting. Healy and Wahlen (1999) note that, ideally, financial reporting should distinguish the best performing firms from the poor performers resulting in more efficient resource allocations. However, financial reporting judgments allow managers to communicate private information about firm value thus producing more reliable and timely financial reports [see Watts and Zimmerman(1986); Dechow (1994); Guay, Kothari and Watts(1996); Subramanyam(1996) and Boone and Raman(2007)]. Alternatively, managers may choose to report opportunistically [Healy (1985); DeAngelo(1998); Tan and Jamal(2006) and Garcia Lara, Garcia Osma and Neophytou(2009)] in an attempt to disguise the failing financial health of the company. Either of these alternatives may motivate management prior to a Chapter 11 filing.

There has been extensive research on earnings management promulgated by academics, accounting standard setters, and regulators. Then Chairman of the SEC, Arthur Levitt, in a 1998 speech entitled "The Numbers Game", expressed concern about earnings management and its impact on financial reporting in the U.S. He notes that "Earnings management threatens the integrity of financial reporting in the U.S." Extant research also suggests that earnings management is prevalent in financial reporting. Byard, Hossain and Mitra (2007) find that firms use income-decreasing earnings management during periods of heightened political cost sensitivity. Jeanjean and Stolowy (2008) find that even the introduction of International Financial Reporting Standards did not cause a reduction in the pervasiveness of earnings management. Ghosh and Olsen (2009) note that when firms operate in highly uncertain environments, managers are more likely to use discretionary accruals to reduce earnings variability and Chan, Farrell and Lee (2008) report that there are more positive and absolute discretionary accruals for firms reporting internal control weaknesses than for other firms. Most relevant to this study, Garcia Lara, et al. (2009) report that bankrupt firms manage their earnings upward in the years prior to failure.

The earnings management technique of interest in this paper is discretionary accruals. Managers may manipulate discretionary accruals to increase earnings and ensure the survival of the company. The motivation for the manipulation may be to deceive investors and/or to inform them of potential future cash flows. Prior research shows that management's actions in the Chapter 11 process may be self-serving (see Hotchkiss, 1995). Franks and Torous (1989) note that it is unlikely that a judge will liquidate a firm if it is expected to have positive future cash flows, while Subramanyam (1996) provides evidence that discretionary accruals are predictors of future earnings and cash flows. Therefore, if managers believe current earnings, including discretionary accruals, will influence the stakeholder's evaluation of future cash flows, they will be motivated to use income increasing discretionary accruals. This research will examine how discretionary accruals differ between companies that are liquidated and those that are reorganized during the three years leading up to the bankruptcy filing. We contend that earnings management may occur prior to a Chapter 11 filing so managers can gain consensus for a reorganization plan.

\section{Methodology}

\subsection{Sample Selection}

The sample of bankrupt firms is compiled from New Generations Research, Inc.'s Bankruptcy Yearbook and Almanac (1991-2004 editions). The final sample includes all firms that filed a Chapter 11 between 1991 and 2004, where financial data are available on Compustat, and the bankruptcy was resolved by either reorganization or liquidation. This timeframe was chosen to avoid bankruptcies resulting from the financial crisis of 2007. Those may have been unexpected, and therefore, earnings management would be unlikely three years prior to the bankruptcy filing. The sample was restricted to companies that elected to file Chapter 11 bankruptcy, so there was at least some possibility of being liquidated versus reorganized. As such, we have eliminated those companies liquidating by electing Chapter 7 bankruptcy.

Panel A of Table 1 shows that of the 483 firms with the appropriate bankruptcy outcomes, 275 firms were lost due to missing Compustat data. We use the performance-adjusted cross-sectional Jones model to estimate discretionary 
accruals. This results in a final sample of 208 firms with data for each of the two years prior to bankruptcy filing and 140 firms with data for each of the three years prior to bankruptcy filing.

Panel B of Table 1 shows that of the 208 firms with data for the two years prior to bankruptcy filing, 156 (75\%) were reorganized and $52(25 \%)$ were liquidated. Of the 140 firms with data for the three year prior to bankruptcy filing, $109(78 \%)$ were reorganized and $31(22 \%)$ were liquidated. These percentages are consistent with that found by Bryan, et al. (2002) and Jacobs, et. al. (2008).

Table 2 shows that the 208 sample firms cover all one-digit SIC codes. The industry with the maximum number of firms is communications (23 or 11.1\%). Other well-represented industries are business services with 17 (8.2\%) firms and electronics with $15(7.2 \%)$ firms. There is no evidence of industry clustering, including internet bankruptcies during the internet bubble around 2003. Industries with several bankruptcies maintained the pattern of more reorganizations than liquidations.

\subsection{The Model}

We investigate the association between firm characteristics in the periods prior to bankruptcy filing and bankruptcy outcome by estimating the following logistic regression model for each of the three years prior to bankruptcy filing:

$$
\text { OUTCOME }=\mathrm{b}_{0}+\mathrm{b}_{1} \mathrm{DA}+\mathrm{b}_{2} \text { POSDA }+\mathrm{b}_{3} \text { SIZE }+\mathrm{b}_{4} \mathrm{SOL}+\mathrm{b}_{5} \text { LIQ }+\mathrm{b}_{6} \text { FREEAT }+\mathrm{b}_{7} \text { LEV }+\varepsilon
$$

Where:

OUTCOME $=$ dummy variable that equals 1 if the firm reorganized and 0 if the firm liquidated;

DA $\quad=$ the magnitude of discretionary accruals;

POSDA $=$ dummy variable that equals 1 if discretionary accruals are positive and 0 otherwise;

SIZE $=$ the natural log of total assets as of the fiscal year end;

SOL $\quad=$ solvency risk, measured as the interest coverage ratio (earnings before extraordinary items plus interest expense/ interest expense);

LIQ $=$ liquidity risk measured as the quick ratio (cash plus receivables/current liabilities);

FREEAT $=$ free assets measured as the gross property, plant and equipment less the collateralized loans divided by total assets;

$\mathrm{LEV}=$ leverage measured as total long-term debt/total assets.

$\varepsilon \quad=\quad$ error term.

We limit our sample to Chapter 11 filings for which bankruptcy was either resolved by reorganization or liquidation. The dependent variable OUTCOME is coded as 1 if the firm reorganized and 0 if the firm liquidated.

First, we examine several variables shown by prior studies to be associated with bankruptcy outcome. Unlike other studies however, we examine these variables for the three years prior to filing. Prior research [see Lopucki(1983); Campbell(1996) and Bryan et al. (2002)] has shown that larger firms are more likely to reorganize than smaller firms. Consistent with this research, we use the natural log of total assets as a proxy for firm size. We expect the coefficient on the SIZE variable to be positive.

The variables SOL and LIQ are measures of firm solvency and liquidity respectively. We include these variables since Bryan, et al. (2002) and Jacobs, et al. (2008) find that solvency risk and short-term liquidity risk are associated with bankruptcy outcome. SOL is measured by the interest coverage ratio. Bryan, et al. (2002) reports a positive association between firm solvency and reorganization. Creditors are more likely to agree to a reorganization plan if the interest coverage ratio is higher. We therefore expect the coefficient on this variable to be positive.

Both Bryan, et al. (2002) and Jacobs, et al. (2008) find that liquidity risk is associated with bankruptcy outcome, but their results are in opposite directions. Though their measures are a bit different, Bryan, et al. (2002) suggest that more liquidity may reflect the company's ability to remain a going concern given short-term credit relief and find less liquid firms are more likely to be liquidated. Jacobs, et al. (2008) posit that if there is cash on hand, the stakeholders may settle for a current payment to settle the debts, and find that poor liquidity is associated with reorganization. LIQ is measured by the quick ratio which was used by Bryan, et al. (2002). We do not predict a direction on this variable.

We include free assets (FREEAT) because Casey, Mcgee and Stickney (1986) and Bryan et al. (2002) investigated free assets and bankruptcy outcome. Higher levels of free assets increased borrowing opportunities which could 
provide funds for operations and reorganization costs, thus increasing the likelihood of the firm emerging from bankruptcy as a viable entity. The variable is operationalized as the property, plant and equipment less collateralized loans divided by total assets. The coefficient on the variable is expected to be positive.

Next, we include the variable LEV as a measure of firm leverage. We measure firm leverage as long-term debt divided by total assets. As firm leverage increases, the bargaining power of creditors will increase. Jacobs et al. (2008) note that as the bargaining power of creditors increase, firms are more likely to file a "prepackaged" bankruptcy, thus increasing the likelihood of reorganization. We predict a positive coefficient for the variable.

Finally, we include two discretionary accruals variables to examine the effect of earnings management on bankruptcy outcome, DA and POSDA. The variable DA is a measure of the magnitude of discretionary accruals. Consistent with prior studies, we assume that high levels of discretionary accruals indicate earnings management [see Healy(1985); Dechow and Sloan(1995), Bartov et al.(2000) and Rosner(2003)]. (By definition, all tests of earnings management are joint tests of (1) earnings management and (2) the discretionary accruals model used (Bernard and Skinner (1996) and Klein (2002).)If the level of discretionary accruals is a predictor of future earnings and cash flows and opportunistic earnings management remains undetected by stakeholders, then there should be a positive association between the level of discretionary accruals and bankruptcy outcome. Alternatively, if shareholders, creditors and the bankruptcy court are able to see through opportunistic earnings management, then the coefficient on DA should be negative. A negative coefficient would indicate that firms with higher levels of discretionary accruals in the periods prior to bankruptcy filing are more likely to liquidate. Accordingly, we do not predict a direction on this variable.

We measure discretionary accruals using the cross-sectional modified Jones (1991) model. Since Dechow et al. (1995) and Kothari (2005) suggest that estimates of discretionary accruals are correlated with firm performance, we also include lagged return on assets (ROA) in the modified Jones (1991) model to control for firm performance [see also Kwon, Lim and Tan(2007)]. We use the cross-sectional modified Jones model because several studies indicate that the Jones and modified Jones model are the best performing models [see DeFond and Jiambalvo (1994); Subramanyam(1996); DeFond and Subramanyam(1998) and Bartov et al.(2000)]. (We also tested the traditional modified Jones model with identical results.)

Consistent with Kothari, Leone and Wasley (2005), we calculate total accruals (TA) as follows:

$$
\mathrm{TA}=\triangle(\text { Current Assets }- \text { Cash })-\triangle(\text { Current Liabilities }- \text { Current }
$$

Portion of Long-Term Debt - Depreciation and Amortization)

and estimate the following model:

$$
\mathrm{TA}_{\mathrm{it}} / \mathrm{A}_{\mathrm{it}-1}=\alpha_{1}\left(1 / \mathrm{A}_{\mathrm{it}-1}\right)+\alpha_{2}\left(\triangle \mathrm{REV}_{\mathrm{it}} / \mathrm{A}_{\mathrm{it}-1}\right)+\alpha_{3} \mathrm{PPE} / \mathrm{A}_{\mathrm{it}-1}+\alpha_{4}\left(\mathrm{ROA}_{\mathrm{it}-1}\right)+\varepsilon_{\mathrm{it}}
$$

Where:

$\mathrm{TA}_{\text {it }}=$ total accruals in year $\mathrm{t}$

$\mathrm{A}_{\mathrm{it}-1} \quad=\quad$ lagged total assets

$\triangle \mathrm{REV}_{\mathrm{it}}=\quad$ change in revenues in year $\mathrm{t}$

$\mathrm{ROA}_{\mathrm{it}-1}=$ return on assets (Net income/total assets) for year $\mathrm{t}-1$

$\mathrm{PPE}_{\mathrm{it}}=$ Gross property plant and equipment in year $\mathrm{t}$.

$\varepsilon_{\text {it }}=$ error term.

We estimate equation (3) separately for all Compustat firms having the same two-digit SIC code to arrive at the alphas for each industry code. We then estimate performance-adjusted discretionary accruals as follows:

$$
\left.D A_{i t}=\left(T A_{i t} / A_{i t-1}\right)-\left[a_{1}\left(1 / A_{i t-1}\right)-a_{2}\left[\left(\triangle R E V_{\text {tit }}-\triangle A_{i t}\right)\right] / A_{i t-1}\right)-a_{3} P P E_{t} / A_{i t-1}+a_{4}\left(R O A_{i t-1}\right)\right]
$$

where: $\mathrm{a}_{1}, \mathrm{a}_{2}, \mathrm{a}_{3}$ and $\mathrm{a}_{4}$ are OLS estimates of $\alpha_{1}, \alpha_{2}, \alpha_{3}$ and $\alpha_{4}$ and $\triangle \mathrm{AR}_{\mathrm{it}}$ is the change in accounts receivable in year t.

POSDA is a dummy variable that is set equal to one if discretionary accruals are positive, and zero otherwise. We posit that if firms manage earnings around bankruptcy filing, they are more likely to use income increasing discretionary accruals to avoid liquidation. A positive coefficient on this variable indicates that firms with positive discretionary accruals in the periods prior to bankruptcy filing are more likely to reorganize, while a negative coefficient indicates that firms with positive discretionary accruals in the periods prior to bankruptcy filing are more likely to liquidate. 
We include both accrual variables since DA measures the magnitude of the discretionary accruals. POSDA, on the other hand, captures if bankruptcy outcome is associated with the recognition of net positive accruals.

\section{Results}

Table 3 reports the correlations among the variables in the year prior to the bankruptcy. These were similar for the other years as well, in that none were highly correlated. Table 4 presents comparative univariate data for the reorganized and liquidated firms for each of the three years prior to bankruptcy filing. For descriptive purposes, we use the parametric t-test and the nonparametric Wilcoxon $\mathrm{Z}$ test to determine significant differences between the two groups. Table 4 shows that relative to the liquidated firms, the reorganized firms are larger and more highly leveraged in each of the three years prior to bankruptcy filing. Two years prior to filing, reorganized firms are more solvent and have higher levels of discretionary accruals than the liquidated firms. A year prior to filing, reorganized firms are more solvent than the liquidated firms. Multivariate tests are required to better understand the relationships noted here.

\subsection{Three Years Prior to Filing.}

Table 5 reports the logistic regression results for each of the three years prior to bankruptcy filing. A positive sign means the likelihood of reorganization increases directly with the value of the dependent variable. Only leverage (LEV) is significant and positive for each of the three years prior to filing. The significantly positive coefficients indicate that firms that eventually reorganize are more highly leveraged than liquidated firms. As bankruptcy approaches, additional characteristics diverge between the two groups.

\subsection{Two Years Prior to Filing.}

Two years prior to bankruptcy filing, the liquidity variable (LIQ) is positive and significant. The significantly positive coefficients indicate that firms with lower liquidity risks are more likely to reorganize. This is consistent with our expectations and prior research (Bryan et al. 2002). This result indicates that liquidity risks can be used to differentiate firms into the reorganized and liquidated groups as early as two years prior to bankruptcy filing. Consistent with our expectation, the firm size variable (SIZE) is also positive and significant two years prior to bankruptcy filing. As mentioned earlier, there is conflicting theory and evidence regarding solvency. In this analysis, the solvency variable (SOL) is significant and positive in the year prior to bankruptcy filing. This indicates that more solvent firms are more likely to reorganize, thus supporting the Bryan, et al.'s argument that liquidity reflects the company's potential to remain a going concern. In summary, our results show that reorganized firms are larger and more solvent, liquid and leveraged in the two years prior to bankruptcy filing. Stakeholders can use this information to project the likely outcome of firms that are expected to file Chapter 11 bankruptcy.

The coefficient on the discretionary accruals variable (DA) is also significant and positive two years prior to the bankruptcy filing. The significantly positive coefficient indicates that companies that reorganize have higher discretionary accruals two years prior to bankruptcy filing. This can be explained in two ways. Companies may be preparing in advance in order to manage the financial position in a way that encourages stakeholders to accept a reorganization plan. Alternatively, these companies may have more flexibility to manage the accruals and use them to inform shareholders of potential positive cash flows. Regardless of the motivation, our results are useful in helping stakeholders predict the eventual outcome of a Chapter 11 filing as early as two year in advance. The behavior of discretionary accruals is significantly different between the two groups two years before the filing.

\subsection{Year Prior to Filing.}

In the last full reporting period before the bankruptcy filing, firms that reorganize are generally healthier, with higher interest coverage (SOL), quick (LIQ), and debt/equity (LEV) ratios. Free assets and size are not significant with our sample in the year prior to bankruptcy filing. These results are consistent with the cross-sectional analysis by Bryan, et al. (2002) which focused only on this year.

In the period prior to bankruptcy filing, the magnitude of the discretionary accruals is not significantly different between the two groups but the dummy variable POSDA is significantly negative indicating that the likelihood of liquidation is associated with positive discretionary accruals in this period. Combining this with the prior year's results, it seems that managers in companies that reorganize are more proactive at managing earnings. The managers in companies that liquidate may be trying to manage earnings a little too late. Stakeholders are not misled by positive discretionary accruals in the final year before bankruptcy. In fact, net positive discretionary accruals in the final year are associated with company management being less likely to renegotiate terms. 


\section{Sensitivity Analysis}

Discretionary accruals can be operationalized in several ways. We conduct a number of sensitivity tests to check the robustness of our results. We used the traditional modified Jones model with the same results. Additionally, we included total accruals (TA) as an explanatory variable into the model. The total accruals variable is insignificant in all three years and the results are essentially the same as those reported in the study.

Next, we examine the effects of positive versus negative accruals on bankruptcy outcome. We estimate the following model:

$$
\begin{aligned}
\text { OUTCOME }= & b_{0}+b_{1} \text { POSDA }+b_{2} \text { ABSDA } * \text { POSDA }+b_{3} \text { ABSDA*NEGDA }+b_{4} \text { SIZE } \\
& +b_{5} \text { SOL }+b_{6} \text { LIQ }+b_{7} \text { FREEAT }+b_{8} \text { LEV }+\varepsilon
\end{aligned}
$$

Where: $\quad \mathrm{ABSDA}=$ the absolute value of discretionary accruals.

NEGDA $=1$ if accrual is negative and 0 otherwise.

All other variables are defined above.

Table 6 presents the results. It better explains the earnings management two years prior to the bankruptcy. Three years prior to bankruptcy, differences in discretionary accruals are insignificant at conventional levels. Two years prior to bankruptcy, the ABSDA*NEGDA variable is significant and negative. This means that among firms with negative discretionary accruals, the magnitude of the accrual is directly related to the likelihood of liquidation, i.e., the more negative the accrual, the greater the likelihood of liquidation. The year prior to the bankruptcy, the POSDA variable is significant and negative indicating that firms with positive discretionary accruals the year before the filing are more likely to liquidate. The liquidating firms are taking greater income decreasing accruals two years prior to filing and then in the year prior to the bankruptcy they reverse the trend by booking more positive accruals. An alternative view is that the reorganization group is better able to smooth accruals by electing less negative accruals is early years. The earnings management behavior is significantly different between the two groups during this time period.

\section{Summary and Conclusion}

Although we control for factors we consider appropriate, there are potential limitations to our findings. First, even though we use several measures to proxy for earnings management, our measures may not be powerful enough to capture earnings management which is unobservable. Our findings are only as good as the model's ability to detect earnings management. Second, although we control for other factors that may be determinants of bankruptcy outcome, our study could be extended by examining other variables (ROA, lagged variables, etc.), other time periods (the internet bubble or the financial crisis), and/or specific industries (high-tech or financial institutions). In addition, comparing the characteristics of liquidating companies using Chapter 7 to those liquidated through Chapter 11 would be an interesting addition to this line of research.

This study extends prior research by noting that during the three years prior to bankruptcy filing the companies slowly evolve into two distinct groups. The change in leverage noted in the prior research begins three years prior to bankruptcy filing while the change in liquidity begins two years prior to filing. These are early signals to stakeholders as to the likelihood of reorganization of the company. Solvency is the last signal as to bankruptcy outcome.

In addition, we show that firms that reorganize have higher levels of discretionary accruals two years prior to the bankruptcy filing. The year prior to the filing, the companies that are eventually liquidated book more positive discretionary accruals. Since shareholders fare better in a reorganization compared to a liquidation, these results give stakeholders a mechanism for evaluating the probable outcome of bankruptcy filing.

\section{References}

Bartov, E., Gul, F. A., Tsui, S. L. (2000). Discretionary accruals models and audit qualifications. Journal of Accounting and Economics 30 (December), 421-452. http://dx.doi.org/10.1016/S0165-4101(01)00015-5

Beneish, M., Press, E. (1995). Interrelation among events of default.Contemporary Accounting Research2 (Fall), 57-84. http://dx.doi.org/10.1111/j.1911-3846.1995.tb00481.x

Bernard, V. L., Skinner, D.J. (1996). What motivates managers' choice of discretionary accruals? Journal of Accounting and Economics 22 (August-December), 313-326. 
Boone, J. P., Raman, K. K. (2007). Does implementation guidance affect opportunistic reporting and value relevance of earnings? Journal of Accounting and Public Policy 26, 160-192.

Bryan, D. M, Tiras, S. L., Wheatley C. M. (2002). The interaction of solvency with liquidity and its association with bankruptcy emergence. Journal of Business Finance \& Accounting 29 (September/October), 935-965. http://dx.doi.org/10.1111/1468-5957.00456

Byard, D., Hossain, M., Mitra, S. (2007). US oil companies' earnings management in response to hurricane Katrina and Rita. Journal of Accounting and Public Policy 26, 733-748. http://dx.doi.org/10.1016/j.jaccpubpol.2007.10.006

Campbell, S.V. (1996). Predicting bankruptcy reorganization for closely held firms.Accounting Horizons 10 (September), 12-25.

Casey, C., Mcgee, V., Stickney, C. (1986). Discriminating between reorganized and liquidated firms inbankruptcy. The Accounting Review 61 (April), 249-262.

Chan, K.C., Farrell B.,Lee, P. (2008). Earnings management of firms reporting material internal control weaknesses under section 404 of the Sarbanes-Oxley Act. Auditing: A Journal of Practice and Theory27 (2) (November), 161-179. http://dx.doi.org/10.2308/aud.2008.27.2.161

Chen, K., Church, B. (1996). Going concern opinions and the market's reaction to bankruptcy filings. Accounting Review 71 (January), 117-28.

Dawkins, M.,Bamber, L. (1998). Does the medium matter? The relations among bankruptcy petitions filing, broadtape disclosure, and the timing of price reactions. Journal of Finance 53 (June), 1149-63. http://dx.doi.org/10.1111/0022-1082.00047

DeAngelo, L. (1998). Managerial competition, information costs, and corporate governance: The use of accounting performance measures in proxy contests. Journal of Accounting and Economics (January), 3-36.

Dechow, P.M. (1994). Accounting earnings and cash flows as measures of firm performance: The role of accounting accruals. Journal of Accounting and Economics 70 (July), 3-42. http://dx.doi.org/10.1016/0165-4101(94)90016-7

Dechow, P.M., Sloan, R.G. (1995). Detecting earnings management. The Accounting Review 70 (April), 193-225.

Defond, M.L., Jiambalvo, J. (1994). Debt covenant violation and manipulation of accruals. Journal of Accounting and Economics 17 (January), 145-176. http://dx.doi.org/10.1016/0165-4101(94)90008-6

Defond, M.L., Subramanyam, K. R. (1998). Auditor changes and discretionary accruals. Journal of Accounting and Economics 25 (February), 36-67.

Franks, J. R., Torous, W. (1989). An empirical investigation of U.S. firms in reorganization. Journal of Finance 3 (July), 747-769.

Garcia Lara, J. M., Garcia Osma B., Neophytou, E. (2009). Earnings quality in ex-post failed firms. Accounting and Business Research 39 (2), 119-138. http://dx.doi.org/10.1080/00014788.2009.9663353

Ghosh, D., Olsen, L. (2009). Environmental uncertainty and managers' use of discretionary accruals. Accounting Organizations and Society.34, 188-205. http://dx.doi.org/10.1016/j.aos.2008.07.001

Guay, W.R., Kothari, S. P., Watts, R. L. (1996). A market-based evaluation of discretionary accrual models. Journal of Accounting Research 4 (Supplement), 83-105. http://dx.doi.org/10.2307/2491427

Healy, P.M. (1985). The effects of bonus schemes on accounting decisions. Journal of Accounting and Economics 7 (April), 85-107. http://dx.doi.org/10.1016/0165-4101(85)90029-1

Healy, P.M., Wahlen, J. M. (1999). A review of the earnings management literature and its implications for standard setting. Accounting Horizons 4 (December), 365-383. http://dx.doi.org/10.2308/acch.1999.13.4.365

Hotchkiss, E.S. (1995). Postbankruptcy performance and management turnover. Journal of Finance 1 (March), 3-21. http://dx.doi.org/10.1111/j.1540-6261.1995.tb05165.x

Jacobs, M., Karagozoglu, A.K., Naples Layish, D. (2008). Understanding and Predicting the Resolution of Financial Distress. Working Paper, U.S. Office of the Comptroller of the Currency.

Jeanjean, T., Stolowy, H. (2008). Do accounting standards matter? An exploratory analysis of earnings management before and after IFRS adoption. Journal of Accounting and Public Policy 27, 480-494. http://dx.doi.org/10.1016/j.jaccpubpol.2008.09.008 
Jensen, M.C. (1991). Corporate control and the politics of finance. Journal of Applied Corporate Finance 4, 13-33. http://dx.doi.org/10.1111/j.1745-6622.1991.tb00603.x

Jones, J. (1991). Earnings Management During Import Relief Investigations. Journal of Accounting Research 29, 193-228. http://dx.doi.org/10.2307/2491047

Klein, A. (2002). Audit committee, board of director characteristics, and earnings management. Journal of Accounting and Economics. 33 (2002), 375-400. http://dx.doi.org/10.1016/S0165-4101(02)00059-9

Kothari, S. P., Leone A. J., Wasley, C. E. (2005). Performance matched discretionary accrual measures. Journal of Accounting and Economics. 39 (1), 163-197. http://dx.doi.org/10.1016/j.jacceco.2004.11.002

Kwon, S.Y., Lim C. Y., Tan. P. M-S. (2007). Legal systems and earnings quality: The role of auditor industry specialization. Auditing: A Journal of Practice and Theory. 26 no. 2 (November), 25-55. http://dx.doi.org/10.2308/aud.2007.26.2.25

Levitt, A. (1998). The numbers game. Speech delivered at the NYU Center for Law andBusiness, New York, NY, September 28 www.sec.gov/news/speech/speecharchive/1998/spch220.txt.

Lopucki, L.M. (1983). The debtor in full control- systems failure under chapter 11 of the bankruptcy code? American Bankruptcy Law Journal 57 (Spring), 99-126.

Rose-Green, E.,. Dawkins, M. (2000). The association between bankruptcy outcome and price reactions to bankruptcy filings. Journal Of Accounting Auditing and Finance 15 (Fall), 425-437.

Rosner, R. L. (2003). Earnings manipulations in failing firms. Contemporary Accounting Research 20 (2), 361-408. http://dx.doi.org/10.1506/8EVN-9KRB-3AE4-EE81

Subramanyam, K. R. 1996). The pricing of discretionary accruals. Journal of Accounting and Economics 22 (August-December), 249-282.

Tan, H-C., Jamal, K. (2006). Effect of accounting discretion on ability of managers to smooth earnings. Journal of Accounting and Public Policy 25, 554-573. http://dx.doi.org/10.1016/j.jaccpubpol.2006.07.007

Watts, R., Zimmerman, J. (1986). Positive Accounting Theory. Englewood Cliffs NJ: Prentice Hall. 
Table 1. Sample Description

\begin{tabular}{|c|c|c|c|}
\hline \multicolumn{4}{|c|}{ Panel A: Sample Selection } \\
\hline \multicolumn{2}{|c|}{ Initial sample with known bankruptcy outcome } & \multicolumn{2}{|c|}{483} \\
\hline \multicolumn{2}{|c|}{ Firms with missing Compustat data } & \multicolumn{2}{|c|}{$\underline{275}$} \\
\hline \multicolumn{2}{|c|}{ Final sample } & \multicolumn{2}{|c|}{208} \\
\hline \multicolumn{4}{|c|}{ Panel B: Distribution of Final Sample in Years Prior to Filing Based on Bankruptcy Outcome } \\
\hline & One Year Before & Two Years Befor & Three Years Before \\
\hline Reorganized firms & 156 & 156 & 109 \\
\hline Liquidated firms & $\underline{52}$ & $\underline{52}$ & $\underline{31}$ \\
\hline Final sample & 208 & 208 & 140 \\
\hline
\end{tabular}

Table 2. Distribution of Bankrupt Firms by Industry and by Outcome

\begin{tabular}{lccrc}
\hline One-digit SIC & Reorganized & Liquidated & Total & Percentage \\
\hline $1000 \mathrm{~s}$ & 12 & 0 & 12 & $5.8 \%$ \\
$2000 \mathrm{~s}$ & 20 & 2 & 22 & $10.6 \%$ \\
$3000 \mathrm{~s}$ & 37 & 10 & 47 & $22.6 \%$ \\
$4000 \mathrm{~s}$ & 31 & 10 & 41 & $19.7 \%$ \\
$5000 \mathrm{~s}$ & 26 & 22 & 48 & $23.1 \%$ \\
$6000 \mathrm{~s}$ & 2 & 1 & 3 & $1.4 \%$ \\
$7000 \mathrm{~s}$ & 15 & 6 & 21 & $10.1 \%$ \\
$8000 \mathrm{~s}$ & $\underline{13}$ & $\underline{1}$ & $\underline{14}$ & $\underline{6.7 \%}$ \\
Total & 156 & 52 & 208 & $100.0 \%$ \\
\hline
\end{tabular}

Table 3. Correlations

\begin{tabular}{lrrrrrr}
\hline & POSDA & SOL & LIQ & SIZE & FREEAT & LEV \\
\hline DA & 0.6096 & -0.0199 & 0.2238 & 0.0432 & -0.0227 & 0.0543 \\
POSDA & & -0.0322 & 0.2029 & -0.1027 & -0.0153 & 0.0436 \\
SOL & & & -0.2172 & 0.2717 & -0.0059 & 0.1491 \\
LIQ & & & & 0.0167 & -0.0850 & -0.3025 \\
SIZE & & & & & -0.0275 & -0.0760 \\
FREEAT & & & & & & -0.1054 \\
\hline
\end{tabular}


Table 4. Descriptive Statistics for Reorganized \& Liquidated Bankrupt Firms in the Years Prior to Bankruptcy

\begin{tabular}{|c|c|c|c|c|c|c|c|c|c|c|}
\hline Variables & Mean & Median & Std. Dev & Mean & Median & Std. Dev & t-statistic & \multicolumn{3}{|c|}{ Wilcoxon Z } \\
\hline \multicolumn{11}{|l|}{ Year t-1 } \\
\hline $\mathrm{N}$ & 156 & & & 52 & & & & & & \\
\hline DA & 0.026 & -0.043 & 0.366 & -0.027 & -0.014 & 0.321 & 0.940 & & 0.110 & \\
\hline SIZE & 5.722 & 5.728 & 1.770 & 5.139 & 5.309 & 1.432 & 2.150 & $* *$ & 2.525 & $*$ \\
\hline SOL & -3.391 & -1.927 & 6.337 & -8.668 & -2.925 & 18.588 & 2.010 & * & 2.470 & * \\
\hline LIQ & 0.635 & 0.347 & 0.756 & 0.573 & 0.362 & 0.587 & 0.610 & & 0.380 & \\
\hline FREEAT & 0.524 & 0.461 & 0.461 & 0.466 & 0.401 & 0.379 & 0.810 & & 0.790 & \\
\hline LEV & 0.775 & 0.685 & 0.568 & 0.581 & 0.511 & 0.447 & 2.240 & $* *$ & 2.575 & ** \\
\hline
\end{tabular}

Year t-2

\begin{tabular}{lrrrrrrrrrr}
$\mathrm{N}$ & 156 & \multicolumn{9}{c}{52} \\
\hline DA & 0.044 & -0.006 & 0.300 & -0.091 & -0.014 & 0.458 & 1.990 & $*$ & 0.990 & \\
SIZE & 5.942 & 5.954 & 1.705 & 5.186 & 5.235 & 1.431 & 2.876 & $* *$ & 3.326 & $* *$ \\
SOL & -3.422 & 0.154 & 16.473 & -35.832 & -1.150 & 145.235 & 1.610 & 2.960 & $* *$ \\
LIQ & 1.097 & 0.761 & 1.071 & 0.987 & 0.668 & 1.012 & 0.650 & 0.990 & \\
FREEAT & 0.418 & 0.357 & 0.400 & 0.435 & 0.418 & 0.367 & 0.280 & 0.350 & \\
LEV & 0.587 & 0.562 & 0.383 & 0.395 & 0.382 & 0.317 & 3.248 & $* *$ & 3.318 & $* *$ \\
\hline
\end{tabular}

Year t-3

\begin{tabular}{|c|c|c|c|c|c|c|c|c|c|c|}
\hline $\mathrm{N}$ & 109 & & & 31 & & & & & & \\
\hline $\mathrm{DA}$ & -0.080 & -0.050 & 0.905 & -0.026 & 0.015 & 0.407 & 0.540 & & 1.580 & \\
\hline SIZE & 5.807 & 5.998 & 1.746 & 4.869 & 5.318 & 0.229 & 3.400 & $* *$ & 3.706 & $* *$ \\
\hline SOL & -1.112 & 0.768 & 7.795 & -39.398 & 0.620 & 196.177 & 1.390 & & 0.460 & \\
\hline LIQ & 1.465 & 0.890 & 3.331 & 1.134 & 0.638 & 1.240 & 1.020 & & 1.780 & \\
\hline FREEAT & 0.369 & 0.365 & 0.446 & 0.404 & 0.371 & 0.344 & 0.570 & & 0.310 & \\
\hline LEV & 0.548 & 0.529 & 0.318 & 0.390 & 0.379 & 0.282 & 2.727 & $* *$ & 2.781 & $* *$ \\
\hline
\end{tabular}

* indicates significance at $\mathrm{p}<0.05$ level based on two-tailed tests.

**indicates significance at $\mathrm{p}<0.01$ level based on two-tailed tests.

Variable Definitions:

OUTCOME =dummy variable that equals 1 if the firm reorganized and 0 if thefirm liquidated;

DA $\quad=$ discretionary accruals measured using the performance adjusted modified Jones model;

SIZE = firm size measured as natural log of total assets as of the fiscal year end;

SOL $\quad=$ firm solvency risk, measured as the interest coverage ratio, i.e., earnings before extraordinary items plus interest expense, divided by interest expense;

LIQ $=$ firm's liquidity measured as the quick ratio, i.e., cash plus receivables divided by current liabilities;

FREEAT $=$ free assets measured as the gross property, plant and equipment less the collateralized loans divided by total;

LEV $\quad=$ long-term debt scaled by total assets; 
Table 5. Logistic Regression Results for the Three Years Prior to Bankruptcy Filing

\begin{tabular}{|c|c|c|c|c|c|c|c|c|c|c|}
\hline \multirow{3}{*}{$\begin{array}{l}\text { Year } \\
\text { Variable }\end{array}$} & \multicolumn{4}{|c|}{$\mathrm{t}-1$} & \multicolumn{3}{|l|}{$\mathrm{t}-2$} & \multicolumn{3}{|l|}{$t-3$} \\
\hline & \multirow{2}{*}{$\begin{array}{l}\text { Exp } \\
\text { Sign }\end{array}$} & \multicolumn{3}{|c|}{ Wald } & \multicolumn{3}{|c|}{ Wald } & \multicolumn{3}{|c|}{ Wald } \\
\hline & & Estimate & $\mathrm{Chi}^{2}$ & Prob. & Estimate & $\mathrm{Chi}^{2}$ & Prob. & Estimate & $\mathrm{Chi}^{2}$ & Prob. \\
\hline \multicolumn{2}{|c|}{ INTERCEPT } & -0.280 & 0.113 & 0.736 & -1.014 & 1.549 & 0.213 & -0.435 & 0.182 & 0.670 \\
\hline DA & $?$ & 0.911 & 1.835 & 0.176 & 1.402 & 3.910 & 0.048 & 0.083 & 0.087 & 0.767 \\
\hline POSDA & $?$ & -0.796 & 3.326 & 0.068 & -0.502 & 1.314 & 0.252 & -0.593 & 1.702 & 0.192 \\
\hline SIZE & + & 0.119 & 1.277 & 0.259 & 0.198 & 3.593 & 0.058 & 0.145 & 0.934 & 0.334 \\
\hline SOL & + & 0.041 & 3.711 & 0.054 & 0.006 & 1.518 & 0.218 & 0.005 & 0.028 & 0.868 \\
\hline LIQ & $?$ & 0.587 & 3.678 & 0.055 & 0.406 & 3.735 & 0.053 & 0.279 & 1.147 & 0.284 \\
\hline FREEAT & + & 0.582 & 1.973 & 0.160 & 0.113 & 0.058 & 0.810 & -0.040 & 0.005 & 0.944 \\
\hline LEV & + & 0.974 & 5.546 & 0.019 & 1.774 & 7.012 & 0.008 & 1.774 & 4.548 & 0.033 \\
\hline \multicolumn{2}{|l|}{$\mathrm{N}$} & 208 & & & 208 & & & 140 & & \\
\hline \multicolumn{2}{|c|}{ Likelihood Ratio } & 23.085 & $(p=.0016)$ & & 30.105 & \multicolumn{2}{|c|}{$(\mathrm{p}<.0001)$} & 9.718 & $(\mathrm{p}=.205)$ & \\
\hline \multicolumn{2}{|c|}{ Wald } & 17.623 & $(\mathrm{p}=.0138)$ & & 19.953 & $(p=.005$ & & 8.005 & $(p=.332)$ & \\
\hline \multicolumn{2}{|c|}{ Percent Concordant } & $71.8 \%$ & & & $74.4 \%$ & & & $69.6 \%$ & & \\
\hline \multicolumn{2}{|c|}{ Max-rescaled $\mathrm{R}^{2}$} & $15.56 \%$ & & & $19.96 \%$ & & & $10.27 \%$ & & \\
\hline
\end{tabular}

All probabilities reported are 2-tailed.

Bold indicates significance at $\mathrm{p}<0.05$ level based on one-tailed tests.

Variable Definitions:

OUTCOME =dummy variable that equals 1 if the firm reorganized and 0 if the firm liquidated;

DA =discretionary accruals measured using the performance adjusted modified Jones model;

SIZE $=$ firm size measured as natural log of total assets as of the fiscal year end;

SOL $=$ firm solvency risk, measured as the interest coverage ratio, i.e., earnings before extraordinary items plus interest expense, divided by interest expense;

LIQ $=$ firm's liquidity measured as the quick ratio, i.e., cash plus receivables divided by current liabilities;

FREEAT = free assets measured as the gross property, plant and equipment less the collateralized loans divided by total;

LEV = long-term debt scaled by total assets; 
Table 6. Logistic Regression Results Breaking Down Positive and Negative Accruals

\begin{tabular}{|c|c|c|c|c|c|c|c|c|c|c|}
\hline Year & \multicolumn{4}{|c|}{$\mathrm{t}-1$} & \multicolumn{3}{|l|}{$\mathrm{t}-2$} & \multicolumn{3}{|l|}{$\mathrm{t}-3$} \\
\hline \multirow[b]{2}{*}{ Variable } & \multirow{2}{*}{$\begin{array}{l}\text { Exp } \\
\text { Sign }\end{array}$} & \multicolumn{3}{|c|}{ Wald } & \multicolumn{3}{|c|}{ Wald } & \multicolumn{3}{|c|}{ Wald } \\
\hline & & Estimate & $\mathrm{Chi}^{2}$ & Prob. & Estimate & $\mathrm{Chi}^{2}$ & Prob. & Estimate & $\mathrm{Chi}^{2}$ & Prob. \\
\hline INTERCEPT & & -0.280 & 0.114 & 0.736 & -0.844 & 1.053 & 0.305 & -0.347 & 0.111 & 0.739 \\
\hline POSDA & $?$ & -0.794 & 3.305 & 0.069 & -0.488 & 1.193 & 0.275 & -0.817 & 2.477 & 0.116 \\
\hline ABSDA*POSDA & $?$ & 0.951 & 0.971 & 0.325 & 0.546 & 0.305 & 0.581 & 1.573 & 0.711 & 0.399 \\
\hline ABSDA*NEGDA & $?$ & -0.869 & 0.774 & 0.379 & -2.120 & 4.077 & 0.044 & 0.013 & 0.001 & 0.971 \\
\hline SIZE & + & 0.119 & 1.250 & 0.264 & 0.190 & 3.302 & 0.069 & 0.136 & 0.786 & 0.375 \\
\hline SOL & + & 0.041 & 3.595 & 0.058 & 0.006 & 1.463 & 0.227 & 0.007 & 0.074 & 0.786 \\
\hline LIQ & $?$ & 0.585 & 3.570 & 0.059 & 0.431 & 4.184 & 0.041 & 0.228 & 0.741 & 0.389 \\
\hline FREEAT & + & 0.584 & 1.971 & 0.160 & 0.113 & 0.056 & 0.813 & 0.003 & 0.000 & 0.996 \\
\hline LEV & + & 0.969 & 5.323 & 0.021 & 1.736 & 6.640 & 0.010 & 1.714 & 4.340 & 0.037 \\
\hline $\mathrm{N}$ & & 208 & & & 208 & & & 140 & & \\
\hline Likelihood Ratio & & 23.145 & $(\mathrm{p}=.0032)$ & & 30.173 & $(\mathrm{p}=.0002$ & & 10.222 & $(\mathrm{p}=.2498$ & \\
\hline Wald & & 17.739 & $(\mathrm{p}=.0233$ & & 19.956 & $(\mathrm{p}=.0105$ & & 8.445 & $(p=.3913$ & \\
\hline Percent Concordant & & $72.1 \%$ & & & $74.4 \%$ & & & $69.9 \%$ & & \\
\hline Max-rescaled $\mathrm{R}^{2}$ & & $15.60 \%$ & & & $20.00 \%$ & & & $10.79 \%$ & & \\
\hline
\end{tabular}

All probabilities reported are 2-tailed.

Bold indicates significance at $\mathrm{p}<0.05$ level based on one-tailed tests.

OUTCOME $=b_{0}+b_{1}$ POSDA $+b_{2}$ ABSDA $*$ POSDA $+b_{3}$ ABSDA $*$ NEGDA $+b_{4}$ SIZE +

$\mathrm{b}_{5} \mathrm{SOL}+\mathrm{b}_{6} \mathrm{LIQ}+\mathrm{b}_{7}$ FREEAT $+\mathrm{b}_{8} \mathrm{LEV}+\varepsilon$

OUTCOME is coded as 1 for reorganization and 0 for liquidation.

ABSDA $=$ the absolute value of the discretionary accrual

$\operatorname{POSDA}=1$ if the accrual is positive; zero otherwise

$\mathrm{NEGDA}=1$ if the accrual is negative; zero otherwise 